\title{
The Self-gap-detecting Zero Power Controlled Electromagnetic Suspension System
}

\author{
Mimpei Morishita Member (Toshiba corp., mimpei.morishita@toshiba.co.jp) \\ Hiroaki Itoh Member (Toshiba corp., hiroaki3.ito@toshiba.co.jp)
}

Keywords: electromagnetic suspension, zero power control, self-gap-detection, state observer, coil electric resistance, adaptive control

\section{Introduction}

The authors succeeded in providing much robustness against the variation of coil resistance with a self-gap-detecting electromagnetic suspension (EMS) system.

Adaptive and non-interaction controls are key issues. This paper proposes this new self-gap-detecting technique. The experimental results will show a validity of the proposed technique and a possibility to apply the self-gap-detecting EMS system to practical apparatuses in industrial fields.

\section{Self-gap-detecting Controller}

2.1 Control Object The control object is shown in Fig. 1. Two magnet units, $\mathrm{HM}_{1}$ and $\mathrm{HM}_{2}$, are located on the top of the levitating body. They are facing to the iron plate. The magnet unit comprises a permanent magnet and a couple of electromagnets.

2.2 Controller The controller consists of an adaptive gain compensator, $\boldsymbol{F}$, a current integrating compensator, $K$ with a saturator, an adaptive state observer, an exciting voltage compensator and a coil resistance evaluator as shown in Fig. 2. The state observer evaluates the air gap lengths and their change rates with respect to time on the basis of the currents and the voltages to excite the magnet units. The exciting voltage compensator calculates compensation voltages to prevent interaction between the control axes, $z$ and $\xi$. The control parameters in this controller are changed by the output of the coil resistance evaluator.

\section{Experiment}

The relation between the variations of the coil resistances and the room temperature is shown in Fig. 3. Figure 4 shows gap length impulse responses for coil resistance variation. The left one is the response at the point, A, in Fig. 3 and the right at the point, B. In Fig. 4, the difference between coil resistances of $\mathrm{HM}_{1}$ and $\mathrm{HM}_{2}$ is $7 \%$ of the nominal value $7.63(\Omega)$. Furthermore, the variation of the each coil resistance is more than $3 \%$. However, the self-gapdetecting EMS system maintains the almost same responses. On the other hand, according to the stability analysis, the variation of only $1.0 \%$ of the nominal coil resistance value brought about unstable levitation to the self-gap-detecting EMS system without the adaptation to coil resistances.

\section{Conclusion}

The authors proposed the new self-gap-detecting technique. The experimental results show that the proposed self-gap-detecting technique is useful and indispensable to industrial application of selfgap-detecting EMS systems.

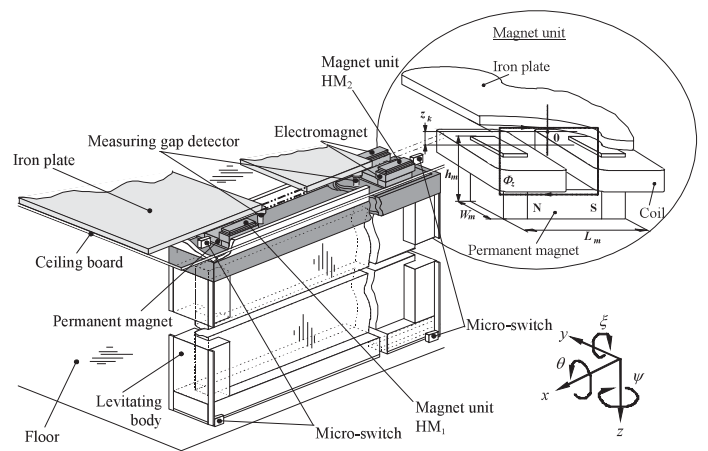

Fig. 1. Control object

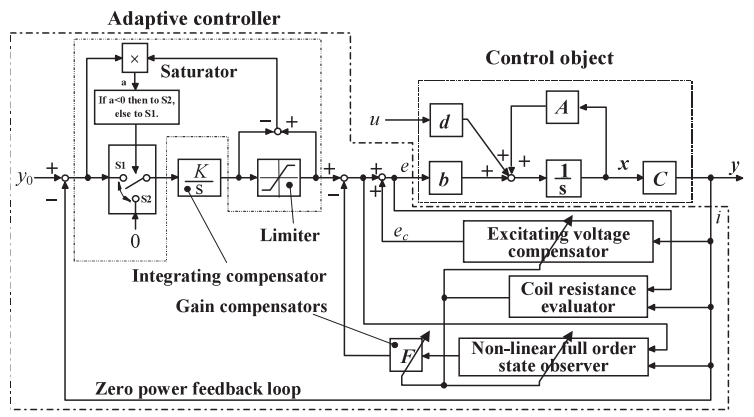

Fig. 2. Controller structure

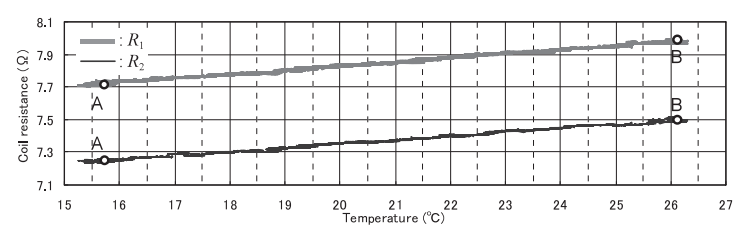

Fig. 3. Coil resistances for room temperature

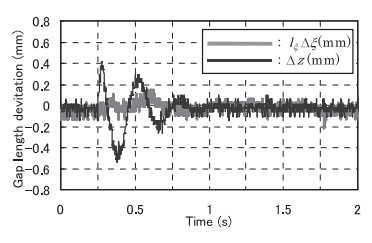

(a) Point A: $R_{1}=7.72(\Omega), R_{2}=$ $7.25(\Omega)$

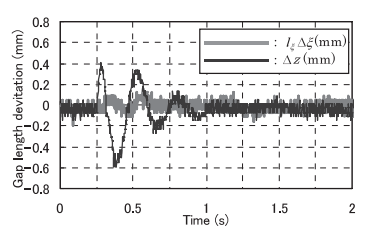

(b) Point B: $R_{1}=7.98(\Omega), R_{2}=$ $7.50(\Omega)$
Fig. 4. Impulse responses at Point A \& B 


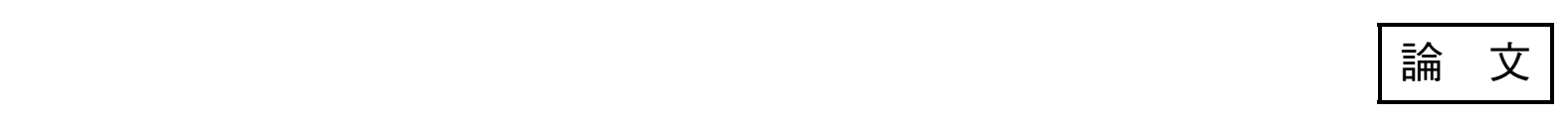

\title{
常電導吸引式磁気浮上系のセンサレスゼロパワー制御
}

\author{
正 員 森下 明平* 正 員 伊東 弘晃*
}

\section{The Self-gap-detecting Zero Power Controlled Electromagnetic Suspension System}

Mimpei Morishita*, Member, Hiroaki Itoh*, Member

There are few self-gap-detecting electromagnetic suspension (EMS) systems robust enough against variation of coil resistance. The authors succeeded in providing much robustness against the variation of coil resistance with a selfgap-detecting EMS system. An adaptive control for coil resistance and an exciting voltage compensator for differences between the coil resistances were applied to the self-gap-detecting EMS system. The adaptive control was applied to the feedback controller and the state observer which evaluates gap length and its change rate with respect to time. As a result, it made clear that this self-gap-detecting controller yields more robustness against mass variation to EMS systems than conventional controllers with gap detectors. This paper proposes this new self-gap-detecting technique. The adaptive control and the exciting voltage compensator will be explained. Moreover, the robustness against mass variation will be discussed. The experimental results will show a validity of the proposed technique and a possibility to apply the self-gap-detecting EMS system to practical apparatuses in industrial fields.

キーワード：常電導吸引式磁気浮上, ゼロパワー制御, センサレス, 状態観測器, コイル抵抗, 適応制御

Keywords: electromagnetic suspension, zero power control, self-gap-detection, state observer, coil resistance, adaptive control

\section{1. はじめに}

常電導吸引式磁気浮上技術は騒音対策や発塵対策として 有効であり, HSST やトランスラピッド等の磁気浮上鉄道 や半導体工場でのクリーンルーム内搬送システムですでに 実用化が図られている(1) (4)。また，エレベータの非接触案 内 ${ }^{(5)}$ やドア ${ }^{(6)}$ への適用が進められている。

常電導吸引式磁気浮上系は浮上ギャップ長の情報を励磁 電圧もしくは励磁電流值にフィードバックして安定化され ている。このため, 従来の制御では浮上ギャップ長の検出 が不可欠であり，実用上ギャップセンサの使用が避けられ なかった。また，ガイドと電磁石間のギャップ長をギャッ プセンサで検出するには, 検出方式に適合したセンサター ゲットおよびターゲット面の管理が必要であった。

このように，センサとそれに付随するセンサターゲット を必要とする浮上ギャップ長の検出は装置のコストを上昇 させる要因となる。また，ギャップセンサの取付けスペー スやセンサターゲット用のスペース確保は装置小型化の障 害となる。とくに，鉄道や搬送システムにおいてはガイド となる軌道に分岐が設けられるため, センサターゲットと

\footnotetext{
* (株) 東芝電力・社会システム技術開発センター

于 183-8511 府中市東芝町 1

Power and Industrial Systems R\&D Center, Toshiba Corp.

1, Toshiba-cho, Fuchu 183-8511
}

ガイドが交差してギャップ長の検出を妨げないような仕組 みが必要であり，システムが複雑化する。

こうした問題を解決するため, ギャップセンサを用いな い安定化技術として様々なセンサレス化手法が提案されて いる。例えば, 電磁石励磁電流からオブザーバ（状態観測 器）によりギャップ長を推定する方法 ${ }^{(7)}$, 交流磁気浮上に より生じる電磁石励磁電圧と励磁電流の位相差に陰に含ま れるギャップ情報を電磁石励磁電圧にフィードバックして 系を安定化する方法 ${ }^{(8)}$ などが提案されている。また, 電磁 石励磁電流值をヒステリシスコンパレータで励磁電流基準 值と比較し, 励磁電流が基準值より大きい場合には電磁石 励磁電圧を負に, 小さい場合は正に切替えてやることでス イッチング周波数を浮上ギャップ長に比例させ浮上系を安 定化する方法 ${ }^{(9)}$ なども検討されている。

しかし，オブザーバを用いる場合では，浮上状態におけ る磁気浮上系の線形モデルからオブザーバが導出されるた め, 浮上状態にないときの浮上ギャップ長の推定ができず, 浮上体がガイドに接触すると浮上状態に移行できないこと が問題となる。また, オブザーバ以外のギャップ情報を含 む物理量で電磁石励磁電圧を制御する場合では, 浮上制御 系が非線形系になるため安定判別が困難なことや, 温度上 昇等に起因して電磁石コイルに電気抵抗の変動があると浮 上状態が維持できなくなることが問題となる。このため, センサレス化手法はいまだ実用化に至っていない。 
本研究では，実用に耐え得るセンサレス化技術の確立を 目指し，制御系設計が容易なオブザーバ方式に以下の制御 機能を付加した。

(i) オブザーバ積分器のリセット機能

(ii) コイル抵抗值推定+オブザーバの抵抗值適応機能

(iii) 不均一コイル抵抗值に対する制御電圧補正機能

(iv) オフセット電圧推定機能

(v) 速度推定值定常偏差除去機能

(vi) コントローラのコイル抵抗值適応機能

その結果, ノミナル值の $60 \%$ コイル抵抗值変動および50\%質 量変動に対する浮上安定性の維持が可能となった。

本論文は，これらの機能をセンサレス磁気浮上の実用化 手段として提案する。また，オブザーバ方式センサレス磁 気浮上がギャップセンサを用いる場合に比べ，質量変動に 対してより高いロバスト安定性を示すことを報告する。

\section{2. 制御対象}

本論文では，二軸の制御で安定化が行える図 1 に示す二 点支持の浮上体を制御対象とする。浮上体は上端左右に磁 石ユニットとして複合磁石 (Hybrid Magnet, 以下 HM と略 す）を備えている。HM は永久磁石を電磁石で挟んで U 字 形状に構成されており，浮上体上部に設置された鉄板に対し て吸引力を作用させる。また，浮上体の四隅には接触を検出 するためのマイクロスイッチが取り付けられている。4つ のマイクロスイッチの on/off 状態から, i) 両方の HM が天 井に着いた姿勢，ii）両方の $\mathrm{HM}$ が床に着いた姿勢，iii) $\mathrm{HM}_{1}$ が天井 $\mathrm{HM}_{2}$ が床に着いた姿勢，iv) $\mathrm{HM}_{1}$ が床 $\mathrm{HM}_{2}$ が天井 に着いた姿勢のうち一つが特定でき，接触時の浮上ギャッ プ長を得ることができる ${ }^{(6)}$ 。

〈2・1 $\rangle$ 浮上系モデル 浮上体の運動は重心の上下動 ( $z$ モード $)$ および重心回りのピッチング（ $\xi$ モード）で表 せる。各運動モードの支配方程式は次のように運動方程式 と電圧方程式で構成される。

$z$ モード：浮上体重心の $z$ 方向の運動

$$
\left.\begin{array}{l}
M \frac{\mathrm{d}^{2} z}{\mathrm{~d} t^{2}}=F_{1}\left(z_{1}, i_{1}\right)+F_{2}\left(z_{2}, i_{2}\right)+M g+u_{z} \\
L_{\infty} \frac{\mathrm{d} i_{z}}{\mathrm{~d} t}+R i_{z}=-N \frac{\mathrm{d}}{\mathrm{d} t}\left(\boldsymbol{\Phi}_{1}\left(z_{1}, i_{1}\right)+\boldsymbol{\Phi}_{2}\left(z_{2}, i_{2}\right)\right)+e_{z}
\end{array}\right\}
$$

$$
\begin{aligned}
& \text { ただし, } \\
& \quad z=\frac{z_{1}+z_{2}}{2}, \quad i_{z}=\frac{i_{1}+i_{2}}{2}, \quad e_{z}=\frac{e_{1}+e_{2}}{2}
\end{aligned}
$$

$\xi$ モード：浮上体重心を通る $y$ 軸回りの回転運動。

$$
\left.\begin{array}{l}
I_{\xi} \frac{\mathrm{d}^{2} \xi}{\mathrm{d} t^{2}}=\frac{I_{\xi}}{2}\left(-F_{1}\left(z_{1}, i_{1}\right)+F_{2}\left(z_{2}, i_{2}\right)\right)+T_{\xi} \\
L_{\infty} \frac{\mathrm{d} i_{\xi}}{\mathrm{d} t}+R i_{\xi}=-N \frac{\mathrm{d}}{\mathrm{d} t}\left(-\boldsymbol{\Phi}_{1}\left(z_{1}, i_{1}\right)+\boldsymbol{\Phi}_{2}\left(z_{2}, i_{2}\right)\right)+e_{\xi}
\end{array}\right\}
$$

$$
\text { ただし， }
$$

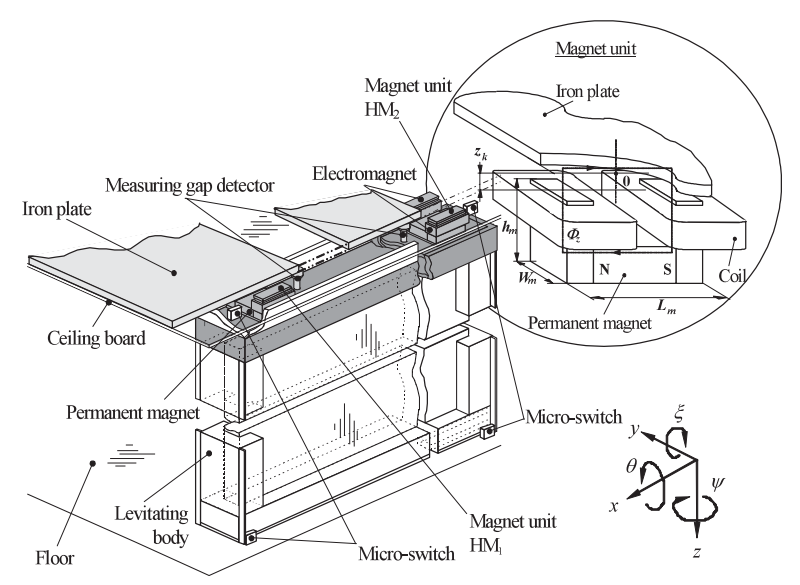

図 1 制御対象

Fig. 1. Control object.

$$
\xi=\frac{-z_{1}+z_{2}}{l_{\xi}}, \quad i_{\xi}=\frac{-i_{1}+i_{2}}{l_{\xi}}, \quad e_{\xi}=\frac{-e_{1}+e_{2}}{l_{\xi}}
$$

ここに添え字 $k$ を $k=1$ or 2 として,$F_{k}$ は $\mathrm{HM}_{k}$ の電磁 力, $\boldsymbol{\Phi}_{k}$ は $\mathrm{HM}_{k}$ の作る主磁束である。これらは $\mathrm{HM}_{1}, \mathrm{HM}_{2}$ の浮上ギャップ長 $z_{k}$, 電磁石励磁電流 (コイル電流) $i_{k}$ を 用いて次のように表せる。

$$
\begin{aligned}
& F_{k}\left(z_{k}, i_{k}\right)=-\mu_{0} S\left(\frac{k_{N} N i_{k}+k_{H m} H_{m} l}{2 z_{k}+\frac{l}{\mu_{S}}}\right)^{2}, \\
& \boldsymbol{\Phi}_{k}\left(z_{k}, i_{k}\right)=\mu_{0} S \frac{k_{S} N i_{k}+k_{H m} H_{m} l}{2 z_{k}+\frac{l}{\mu_{S}}}
\end{aligned}
$$

ここで, $g$ : 重力加速度, $\mu_{0}$ : 真空の透磁率, $M$ : 浮上体質量, $I_{\xi}$ : 浮上体重心回りのピッチング方 向慣性モーメント, $l_{\xi}: \mathrm{HM}_{1}, \mathrm{HM}_{2}$ 間の中心間距 離, $u_{z}: z$ 方向の外力, $T_{\xi}: \xi$ 方向の外乱トルク, $N$ : 各 HM 電磁石コイルの卷回数, $L_{\infty}: z_{k} \rightarrow \infty$ に扩ける各 HM 電磁石コイルの自己インダクタン ス, $R: \mathrm{HM}_{k}$ 電磁石コイルの電気抵抗, $e_{k}: \mathrm{HM}_{k}$ 電磁石コイルの励磁電圧。また, $k_{N}, k_{H m}, k_{S}$ お よび $\mu_{S}$ はそれぞれ近似倸数， $H_{m}, l$ および $S$ は それぞれ永久磁石の保持力，磁極方向の長さ，主 磁束の磁路面積である。

センサレス化を図る場合, 磁気浮上系の制御出力（コン トローラへの入力信号) は $i_{k}$, 制御入力 (コントローラから の出力）は $e_{k}$ となる。ここでは $i_{k}$ の検出に各 $\mathrm{HM}$ 電磁石 コイルに直列に挿入された $0.5(\Omega)$ の抵抗を使用する。制 御入力 $e_{k}$ はコントローラ出力であり, コイル電流 $i_{k}$ と励 磁電圧 $e_{k}$ をもちいて各 $\mathrm{HM}$ の浮上ギャップ長とその変化 速度を推定する。

〈2・2〉線形モデル 本研究では, 線形制御理論によ りセンサレス磁気浮上系の安定化を図る。

(1) 式, (2) 式を平衡点, すなわち $z$ モードでは浮上ギャッ プ長 $z=z_{0}$, コイル電流 $i_{z}=0, \xi$ モードではピッチ角 $\xi=0$, コイル電流 $i_{\xi}=0$ の近傍で線形近似すると各モードに関し, 
次の状態方程式を得る。

$$
\left.\begin{array}{rl}
z \text { モード } & \\
\Delta \ddot{z} & =\frac{2}{M} \frac{\partial F_{z}}{\partial z} \Delta z+\frac{2}{M} \frac{\partial F_{z}}{\partial i_{z}} \Delta i_{z}+\frac{1}{M} u_{z} \\
\Delta \dot{i_{z}} & =-\frac{N}{L_{z 0}} \frac{\partial \boldsymbol{\Phi}_{z}}{\partial z} \Delta \dot{z}-\frac{R}{L_{z 0}} \Delta i_{z}+\frac{1}{L_{z 0}} e_{z}
\end{array}\right\} .
$$

乡モード :

$$
\left.\begin{array}{rl}
\Delta \ddot{\xi} & =\frac{l_{\xi}^{2}}{2 I_{\xi}} \frac{\partial F_{z}}{\partial z} \Delta \xi+\frac{l_{\xi}^{2}}{2 I_{\xi}} \frac{\partial F_{z}}{\partial i_{z}} \Delta i_{\xi}+\frac{1}{I_{\xi}} T_{\xi} \\
\Delta \dot{i}_{\xi} & =-\frac{N}{L_{z 0}} \frac{\partial \boldsymbol{\Phi}_{z}}{\partial z} \Delta \dot{\xi}-\frac{R}{L_{z 0}} \Delta i_{\xi}+\frac{1}{L_{z 0}} e_{\xi}
\end{array}\right\}
$$

(3) 式, (4) 式中, $\Delta$ : 平衡点からの偏差, 記号 “.”: 時間微分演算子 $\frac{\mathrm{d}}{\mathrm{d} t}, \frac{\partial}{\partial z}, \frac{\partial}{\partial i_{z}}$ : 平衡点 $\left(z=z_{0}, i_{z}=0\right)$ における $z$ および $i_{z}$ に関する偏微分值,

$$
\begin{aligned}
& F_{z}: F_{z}\left(z, i_{z}\right)=F_{2}\left(z_{2}, i_{2}\right), \\
& \boldsymbol{\Phi}_{z}: \boldsymbol{\Phi}_{z}\left(z, i_{z}\right)=\boldsymbol{\Phi}_{2}\left(z_{2}, i_{2}\right), \\
& L_{z 0}: L_{z 0}=L_{\infty}+N \frac{\partial \boldsymbol{\Phi}_{z}}{\partial i_{z}}
\end{aligned}
$$

$z$ モードにおけるコイル電流 $i_{z}$ を制御出力とする (3) 式お

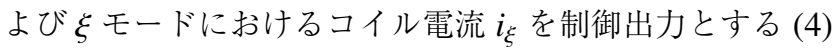
式の浮上系モデルは同一個所に要素を持つ次の状態方程式 で表せる。このとき, HM コイル駆動系および電流検出系 に混入するオフセット成分を考慮する。

$$
\left.\begin{array}{l}
\dot{\boldsymbol{x}}=\boldsymbol{A} \boldsymbol{x}+\boldsymbol{b}\left(e+e_{o f f}\right) \boldsymbol{d} u \\
\boldsymbol{y}=\boldsymbol{C} \boldsymbol{x}+y_{o f f}
\end{array}\right\}
$$

ただし，状態べクトル $\boldsymbol{x}$ ，システム行列 $\boldsymbol{A}$ ，制御 行列 $\boldsymbol{b}$, 外乱行列 $\boldsymbol{d}$ および出力行列 $\boldsymbol{C}$ は,

$$
\begin{aligned}
\boldsymbol{x} & =\left[\begin{array}{c}
\Delta z \\
\Delta \dot{z} \\
\Delta i_{z}
\end{array}\right] \text { or }\left[\begin{array}{c}
\Delta \xi \\
\Delta \dot{\xi} \\
\Delta i_{\xi}
\end{array}\right], \quad \boldsymbol{C}=\left[\begin{array}{lll}
0 & 0 & 1
\end{array}\right] \\
\boldsymbol{A} & =\left[\begin{array}{ccc}
0 & 1 & 0 \\
a_{21} & 0 & a_{23} \\
0 & a_{32} & a_{33}
\end{array}\right], \quad \boldsymbol{b}=\left[\begin{array}{c}
0 \\
0 \\
b_{31}
\end{array}\right], \quad \boldsymbol{d}=\left[\begin{array}{c}
0 \\
d_{21} \\
0
\end{array}\right],
\end{aligned}
$$

であり，

$$
\begin{gathered}
a_{21}=\frac{2}{M} \frac{\partial F_{z}}{\partial z} \text { or } \frac{l_{\xi}^{2}}{2 I_{\xi}} \frac{\partial F_{z}}{\partial z}, a_{23}=\frac{2}{M} \frac{\partial F_{z}}{\partial i_{z}} \text { or } \frac{l_{\xi}^{2}}{2 I_{\xi}} \frac{\partial F_{z}}{\partial i_{z}} \\
a_{32}=-\frac{N}{L_{z 0}} \frac{\partial \Phi_{z}}{\partial z}, \quad a_{33}=-\frac{R}{L_{z 0}}, \\
b_{31}=\frac{1}{L_{z 0}}, \quad d_{21}=\frac{1}{M} \text { or } \frac{1}{I_{\xi}}, \quad e=e_{z} \text { or } e_{\xi}, \\
u=u_{z} \text { or } T_{\xi}, e_{o f f}=e_{z o f f} \text { or } e_{\xi o f f}, y_{o f f}=y_{z o f f} \text { or } y_{\xi o f f} \\
\text { となる。ここで, } e_{z o f f}, e_{\xi o f f} \text { はそれぞれ } \text { モード, } \\
\xi \text { モードにおける制御入力 } e \text { のオフセット成分, } \\
y_{z o f f,} y_{\xi o f f} \text { はそれぞれzモード, } \xi \text { モードにおける } \\
\text { 制御出力 } y \text { のオフセット成分である。 }
\end{gathered}
$$

\section{3. 浮上制御系の基本構成}

浮上ギャップ長とその速度を推定するオブザーバにはコ イル電流と励磁電圧を入力するが，励磁電圧には実際にコ イルを励磁する電圧ではなく, コントローラ内の計算值を 使用する。

〈3.1〉 同一次元オブザーバ

(5) 式の同一次元オブ ザーバは下式で与えられる(10)。

$$
\left.\begin{array}{l}
\dot{\hat{z}}_{o b}=\hat{\boldsymbol{A}} \hat{z}_{o b}+\hat{\boldsymbol{B}} y+\hat{\boldsymbol{E}} e \\
\hat{\boldsymbol{x}}=\hat{\boldsymbol{C}}_{\boldsymbol{a} b} \hat{z}_{o b}+\hat{\boldsymbol{D}} \boldsymbol{y}
\end{array}\right\}
$$

ただし， $\hat{z}_{o b}$ :オブザーバの内部変数であり，オブ ザーバ出力 $\hat{x}$ および各行列 $\hat{A}, \hat{B}, \hat{E}, \hat{C}_{o b}, \hat{D}$ は それぞれ

$$
\begin{aligned}
& \hat{\boldsymbol{x}}=\left[\begin{array}{c}
\Delta \hat{z} \\
\Delta \hat{\dot{z}} \\
\Delta i_{z}
\end{array}\right] \text { or }\left[\begin{array}{c}
\Delta \hat{\xi} \\
\Delta \hat{\dot{\xi}} \\
\Delta i_{\xi}
\end{array}\right], \quad \hat{z}_{o b}=\left[\begin{array}{l}
\hat{z}_{o b 1} \\
\hat{z}_{o b 2} \\
\hat{z}_{o b 3}
\end{array}\right], \hat{\boldsymbol{A}}=\boldsymbol{A}-\hat{\boldsymbol{B} C}, \\
& \hat{\boldsymbol{B}}=\left[\begin{array}{l}
\alpha_{1} \\
\alpha_{2} \\
\alpha_{3}
\end{array}\right], \hat{\boldsymbol{E}}=\boldsymbol{b}, \hat{\boldsymbol{C}}_{\boldsymbol{o b}}=\left[\begin{array}{lll}
1 & 0 & 0 \\
0 & 1 & 0 \\
0 & 0 & 0
\end{array}\right], \hat{\boldsymbol{D}}=\boldsymbol{C}^{\mathbf{T}}
\end{aligned}
$$

である。ここに， $\alpha_{1}, \alpha_{2}, \alpha_{3}$ はオブザーバの推定 速度設定時に決定される值， T は転置行列を表す 記号である。

$\boldsymbol{B}$ は三次の Bessel filter に関する特性根モデルマッチン グ法で決定する。Bessel filterにはステップ応答に対して高 速追従かつ低オーバーシュートという性質がある。浮上体 のノミナル質量を $M_{0}$ としてオブザーバの特性方程式

$$
\operatorname{det}\left[s \mathbf{I}_{3}-\hat{A}\right]=0
$$

から求まる $s$ の多項式の係数と, 三次の Bessel filter の特 性方程式

$$
s^{3}+\frac{6}{\sigma} s^{2}+\frac{15}{\sigma^{2}} s+\frac{15}{\sigma^{3}}=0
$$

で得られる $\mathrm{s}$ の多項式の係数が一致するよう $\alpha_{1}, \alpha_{2}, \alpha_{3}$ を 決定する。ただし $, s:$ ラプラス演算子, $\mathbf{I}_{j}: j \times j$ の単位行 列， $\sigma$ : 収束の速さを決める収束半径である。

(6) 式のオブザーバでは,

$$
\hat{B}=\left[\begin{array}{c}
\frac{15}{a_{21} a_{32} \sigma^{3}}+\frac{6}{a_{32} \sigma} \\
\frac{a_{21}+a_{23} a_{32}}{a_{32}}+\frac{15}{a_{32} \sigma^{2}} \\
a_{33}+\frac{6}{\sigma}
\end{array}\right] .
$$

となる。オブザーバのブロック図を図 3 に示す。

ここで $\hat{\boldsymbol{x}}$ 中の電流推定值に電流検出值を用いるのは, HM を励磁する駆動系に混入するオフセット電圧に対し，電流 推定值が偏差を生じるためである。 


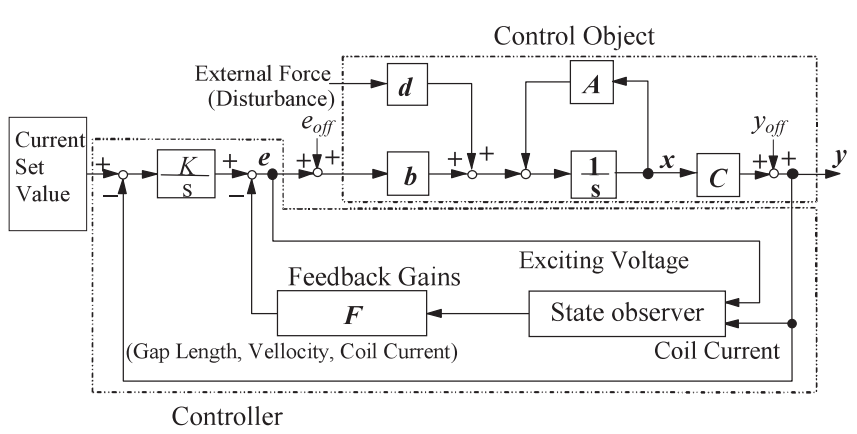

図 2 コントローラの基本構成

Fig. 2. Basic structure of controller.

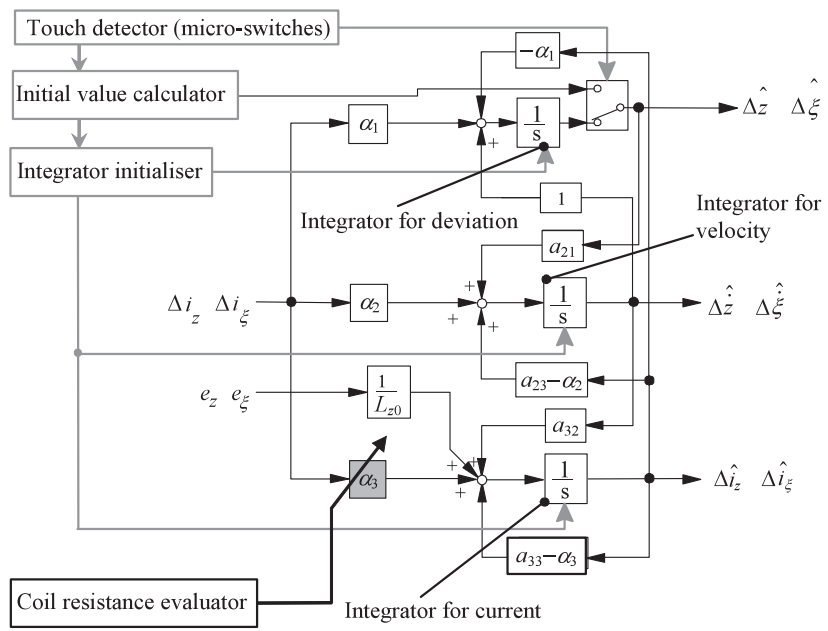

図 3 同一次元オブザーバの構成

Fig. 3. Full order state observer.

$\langle\mathbf{3} \cdot \mathbf{2}\rangle$ 電流積分型コントローラ 制御入力 $e$ はフィー ドバック定数を $\boldsymbol{F}, \boldsymbol{K}$ として,

$$
e=-\boldsymbol{F} \hat{\boldsymbol{x}}+\boldsymbol{K} \int\left(y_{0}-y\right) \mathrm{d} t .
$$

で与える。

$$
\begin{aligned}
& \text { ただし， } \\
& \boldsymbol{F}=\left[\begin{array}{lll}
F_{1} & F_{2} & F_{3}
\end{array}\right], \quad \boldsymbol{K}=K_{3},
\end{aligned}
$$

$y_{0}:$ 各モードのコイル電流目標值。

(8) 式のアナログ制御系のブロック図を図 2 に示す。浮 上ギャップ長をオブザーバで推定すると定常状態でコイル 電流がゼロに収束する状態が得られるが，ここでは後述の ようにコイル抵抗值を測定するため, 微小な測定用電流を 通電する。このため，コントローラを図 2 の構成としてコ イル電流検出值を積分器に導入し, コイル電流を抵抗測定 に必要な電流值に収束させる。

$$
\begin{gathered}
\boldsymbol{F}, \boldsymbol{K} \text { は, (8) 式から } \\
v=\int y \mathrm{~d} t,
\end{gathered}
$$

を定義し，(5) 式の制御対象，(6) 式の同一次元オブザーバ および (8) 式の電流積分形コントローラを結合した次式の
拡大系から決定する。

$$
\begin{aligned}
\frac{\mathrm{d}}{\mathrm{d} t}\left[\begin{array}{c}
\boldsymbol{x} \\
\hat{z}_{\boldsymbol{o b}} \\
v
\end{array}\right]= & {\left[\begin{array}{ccc}
\boldsymbol{A}-\boldsymbol{b} \boldsymbol{F} \hat{\boldsymbol{D}} \boldsymbol{C} & -\boldsymbol{b} \boldsymbol{F} \hat{\boldsymbol{C}} \boldsymbol{D}_{\boldsymbol{o b}} & -\boldsymbol{b} \boldsymbol{K} \\
\hat{\boldsymbol{B}} \boldsymbol{C}-\hat{\boldsymbol{E}} \boldsymbol{F} \hat{\boldsymbol{D}} \boldsymbol{C} & \hat{\boldsymbol{A}}-\hat{\boldsymbol{E}} \boldsymbol{F} \hat{\boldsymbol{C}} \boldsymbol{D}_{\boldsymbol{o b}} & -\hat{\boldsymbol{E}} \boldsymbol{K} \\
\boldsymbol{C} & \mathbf{0}_{1 \times 3} & 0
\end{array}\right]\left[\begin{array}{c}
\boldsymbol{x} \\
\hat{\boldsymbol{z}}_{\boldsymbol{o b}} \\
v
\end{array}\right] } \\
& +\left[\begin{array}{c}
\boldsymbol{d} \\
\boldsymbol{0}_{3 \times 1} \\
0
\end{array}\right] u-\left[\begin{array}{c}
\mathbf{0}_{3 \times 1} \\
\mathbf{0}_{3 \times 1} \\
1
\end{array}\right] y_{0}+\left[\begin{array}{c}
\boldsymbol{b} \\
\mathbf{0}_{3 \times 1} \\
0
\end{array}\right] e_{o f f}+\left[\begin{array}{c}
-\boldsymbol{b} \boldsymbol{F} \hat{\boldsymbol{D}} \\
-\hat{\boldsymbol{E} \boldsymbol{F} \hat{\boldsymbol{D}}} \\
1
\end{array}\right] y_{o f f}
\end{aligned}
$$

ただし， $\mathbf{0}_{i \times j}: i \times j$ のゼロ行列，

$$
\boldsymbol{D}_{o b}=\left[\begin{array}{lll}
1 & 0 & 0 \\
0 & 1 & 0
\end{array}\right], \quad \hat{\boldsymbol{C}}=\boldsymbol{D}_{o b}{ }^{\mathbf{T}} .
$$

$z$ モードであれば浮上体質量, $\xi$ モードであれば慣性モーメ ントを $M$ として, コイル抵抗值 $R$ と $M$ が $R_{\text {min }} \leq R \leq R_{\text {max }}$, $M_{\text {min }} \leq M \leq M_{\text {max }}$ の範囲で拡大系 (9) 式の特性根につい て, 高速・低振動な収束が得られるよう最大実部および最大 実部を持つ特性根の偏角が最小となるように文献 (11), (12) の手法を用いて $\boldsymbol{F}, \boldsymbol{K}$ を求める。

すなわち，次の評価関数で制御入力を決定する。

$$
V(W(M, R), \boldsymbol{P})=\sum_{\substack{M=M_{\min }, M_{1}, \cdots, M_{\max } \\ R=R_{\min }, R_{1}, \cdots, R_{\max }}} W(M, R) \mathrm{e}^{\lambda_{\mathrm{Re}}}
$$

ただし， $W: M, R$ を変数とする重み関数,

$$
\boldsymbol{P}:\left(\boldsymbol{T}_{\boldsymbol{F}}, \boldsymbol{T}_{\boldsymbol{K}}, \sigma\right) \text { なる制御パラメータ。 }
$$

また，上式中， $\lambda_{\operatorname{Re}}$ は次式で定義されている。

$$
\begin{aligned}
& \lambda_{R e}\left(M, R, \boldsymbol{T}_{F}, \boldsymbol{T}_{\boldsymbol{K}}, \sigma\right) \stackrel{\text { def }}{=} \max \{\operatorname{Re}(\lambda): \\
& \operatorname{det}\left[\begin{array}{c}
\lambda \mathbf{I}_{3}-\boldsymbol{A}(M, R)+\boldsymbol{b}(M) \boldsymbol{F}_{0} \boldsymbol{T}_{F} \hat{\boldsymbol{D}} \boldsymbol{C} \\
-\hat{\boldsymbol{B}}(\sigma) \boldsymbol{C}+\hat{\boldsymbol{E}} \boldsymbol{F}_{0} \boldsymbol{T}_{F} \hat{\boldsymbol{D}} \boldsymbol{C} \\
\boldsymbol{C}
\end{array}\right. \\
& \left.\begin{array}{cc}
\boldsymbol{b}(M) \boldsymbol{F}_{0} \boldsymbol{T}_{F} \hat{\boldsymbol{C}} & -\boldsymbol{b}(M) \boldsymbol{K}_{0} \boldsymbol{T}_{\boldsymbol{K}} \\
\lambda \mathbf{I}_{3}-\hat{\boldsymbol{A}}(\sigma)+\hat{\boldsymbol{E}} \boldsymbol{F}_{0} \mathbf{T}_{F} \hat{\boldsymbol{C}} & \hat{\boldsymbol{E}} \\
\mathbf{0} & \lambda
\end{array}\right]=0, \\
& \operatorname{Re}(\lambda) \cos (\arg (\lambda)-\pi)\}
\end{aligned}
$$

ただし， $\boldsymbol{T}_{F}, \boldsymbol{T}_{K}: \boldsymbol{F}, \boldsymbol{K}$ の初期值 $\boldsymbol{F}_{0}, \boldsymbol{K}_{0}$ に乗じ る調整ゲインで

$$
\boldsymbol{T}_{\boldsymbol{F}}=\operatorname{diag}\left[\begin{array}{lll}
t r_{1} & t r_{2} & t r_{3}
\end{array}\right], \quad \boldsymbol{T}_{\boldsymbol{K}}=t r_{K 3}
$$

である。

制御パラメータ $\boldsymbol{F}, \boldsymbol{K}$ は初期值 $\boldsymbol{F}_{0}, \boldsymbol{K}_{0}$ を出発点として (10) 式を最小化 (極小化) する $\left(\boldsymbol{T}_{F}, \boldsymbol{T}_{K}, \sigma\right)$ を求めて次式で 決定する。 


$$
\boldsymbol{F}=\boldsymbol{F}_{0} \boldsymbol{T}_{\boldsymbol{F}}, \quad \boldsymbol{K}=\boldsymbol{K}_{0} \boldsymbol{T}_{\boldsymbol{K}}
$$

ノミナル值における拡大系の特性方程式は

$$
\operatorname{det}\left|\mathbf{s} \mathbf{I}_{3}-\hat{A}\right| \operatorname{det}\left|\mathbf{S} \mathbf{I}_{4}-\boldsymbol{A}_{\boldsymbol{F} \boldsymbol{B}}\right|=0
$$

ただし，

$$
A_{F B}=\left[\begin{array}{cc}
A-b F & -b K \\
C & 0
\end{array}\right]
$$

で与えられるので, (11) 式左辺第二項から得られる特性方 程式と，(10) 式で決定された $\boldsymbol{F}, \boldsymbol{K}$ 值から計算される特性 方程式

$$
s^{4}+c_{3} s^{3}+c_{2} s^{2}+c_{1} s+c_{0}=0
$$

との係数比較から $\boldsymbol{F}, \boldsymbol{K}$ を多項式 (12) 式の $s$ の係数 $c_{i}$ （i=1４）で表すと次式となる。

$$
\begin{aligned}
& F_{1}=\frac{c_{1}+a_{21} c_{3}}{a_{23} b_{31}}, \quad F_{2}=\frac{a_{21}{ }^{2}+a_{21} a_{23} a_{32}+c_{0}+a_{21} c_{2}}{a_{21} a_{23} b_{31}}, \\
& F_{3}=\frac{a_{33}+c_{3}}{b_{31}}, \quad K_{3}=-\frac{c_{0}}{a_{21} b_{31}} \ldots \ldots \ldots \ldots \ldots(13)
\end{aligned}
$$

\section{4. 制御機能の高度化}

制御系基本構成は次の問題点を有している。

i）接触状態でオブザーバの推定が出来ない。

ii）コイル抵抗值の変動に対してロバスト安定性が低い。

iii) 複数の磁石ユニットのコイル抵抗值が異なると制御 軸が干渉する。この干渉は浮上開始や浮上状態への リカバリーを困難にする。

問題点 i) に対しては，接触状態での既知の浮上ギャップ 長を推定值としてオブザーバから出力させるとともに，才 ブザーバを構成する積分器の演算結果をゼロにリセット（初 期化）して浮上状態への移行直後から再び積分を開始させ る機能が浮上開始および再浮上の際に有効に機能すること を検証した (6)。ブロック図を図 3 中に灰色太線で示す。

問題点 ii) については，コイル抵抗值をリアルタイムで推 定し，コイル抵抗值の変動に対して適応オブザーバを構成 する。

(6) 式のオブザーバでは図 3 において灰色で示した $\alpha_{3}$ の みがコイル抵抗 $R$ で変化する。 $\alpha_{3}$ は,

$$
\alpha_{3}=-\frac{R}{L_{z 0}}+\frac{6}{\sigma}
$$

であるから，コイル電流 $i_{k}$ とコイル励磁電圧 $e_{k}$ から $R$ を 求め，(14) 式に基づいて (7) 式の $\boldsymbol{B}$ を $R$ の変動に対して適 応化する ${ }^{(13)}$ 。

問題点 iii) では, 各磁石ユニットから制御軸モードへの変 換行列を $\boldsymbol{T}_{\boldsymbol{u m}}$, 各磁石ユニットの抵抗值を $\boldsymbol{R}_{k}(k=1 \sim n)$ として, 補正電圧 $\boldsymbol{e}_{c}$ を

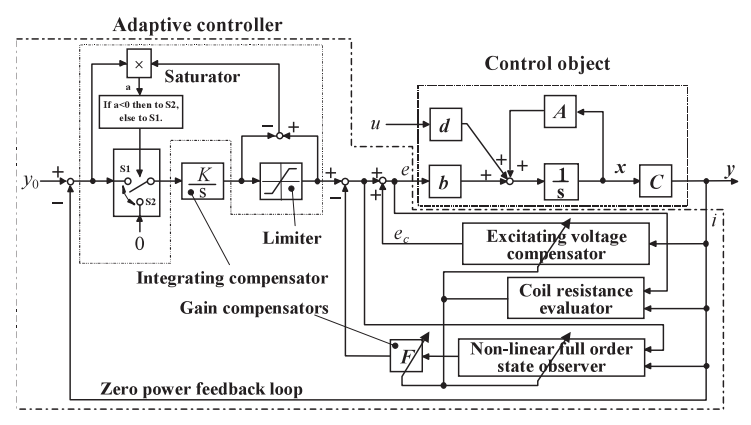

図 4 コイル抵抗值適応形コントローラの構成

Fig. 4. Controller structure.

$$
\begin{aligned}
& \boldsymbol{e}_{\boldsymbol{C}}=\boldsymbol{R}_{\boldsymbol{m}} \boldsymbol{i}_{\boldsymbol{m}}-R_{a} \boldsymbol{i}_{\boldsymbol{m}} \\
& \boldsymbol{R}_{\boldsymbol{m}}=\boldsymbol{T}_{u m}\left[\begin{array}{cccc}
R_{1} & 0 & \cdots & 0 \\
0 & R_{2} & & \vdots \\
\vdots & & \ddots & 0 \\
0 & \cdots & 0 & R_{n}
\end{array}\right] \boldsymbol{T}_{u m}^{-1} \cdot[\ldots \ldots \ldots
\end{aligned}
$$

で定義し, 各モードの制御入力となるモード励磁電圧 $\boldsymbol{e}_{m}$ に $\boldsymbol{e}_{c}$ を加算して非干渉化する ${ }^{(14)}$ こここで, $R_{a}$ は各磁石ユニッ トコイル抵抗の平均值である。

これらの機能を基本制御系に追加し, 抵抗値適応オブバー バを用いると以下の問題点が浮上する。

iv) コイル抵抗值推定用電流指令值 $i_{z 0}$ を小さく設定す るため, 制御ループに混入するオフセット電圧でコ イル抵抗推定精度が悪化する。

v) 制御回路中のオフセット電圧 $e_{\text {off }}$, 電流検出オフセッ ト $y_{\text {off }}$ および電流目標值 $i_{z 0}$ の変化でオブザーバの 推定值が変動する。

vi）抵抗值の変動で浮上系の過渡応答が変化する。この ため, 抵抗值変動が大きくなると浮上系が不安定と なる。

問題点iv) では，抵抗推定の精度をあげるために $i_{z 0}$ を大 きくすると,コイルでの発熱で抵抗值が変動する。このた め, 本研究ではコイルでの電力消費が $0.1(\mathrm{~W})$ 以下になる よう $i_{z 0}$ を設定する。この場合, オフセット電圧を考慮して 抵抗推定の精度を向上させる。

問題点 v) では, オフセット電圧が速度推定值に定常偏差 を生じさせることを利用してオブザーバの推定值変動を抑 制する。とくに, 速度推定值の変動はコイル抵抗推定值の 誤差要因になる。

また，問題点 vi）においてはフィードバックゲインを抵 抗值に対して適応化する。

最終的に得られたコントローラの構成を図 4 に示す。図 中, Exciting voltage compensator は (15) 式を演算する励磁 電圧補償器, Limiter と条件スイッチで構成される Saturator は電流積分補償器に飽和機能を与えている ${ }^{(15)}$ 。

〈4・1 オ オフセット電圧補償 各 HM のコイル抵抗測 定值 $R_{k}$ は分母がゼロにならないよう電力に基づいて, 


$$
R_{k}=\frac{\left(\frac{a_{32}}{b_{31}} \hat{\vec{z}}_{k}+e_{k}-\frac{1}{b_{31}} \frac{\mathrm{d} i_{k}}{\mathrm{~d} t}\right) i_{k}}{i_{k}^{2}+\varepsilon} .
$$

で計算される。ただし， $\varepsilon$ は $0<\varepsilon \ll 1, \hat{z}_{k}$ は各モードの 速度推定值 $\hat{z}_{o b 2}$ から得られる $\mathrm{HM}_{k}$ の浮上ギャップ速度推 定值である。しかし，各コイルへの電圧出力に混入する電 圧オフセット $e_{o f f k}$ および各コイル電流の検出時に混入する 検出オフセット $i_{\text {offk }}$ が存在する場合, (16) 式について再考 が必要となる。

浮上系が安定であれば電流積分器の入力がゼロとなるの で電圧基準をコントローラ内のゼロ電圧とすると, オフセッ 卜を考慮した場合の各コイルに㧍ける電圧方程式は,

$$
e_{k}+e_{o f f k}=R_{k} i_{k}+\gamma_{k}(t) .
$$

となる。ただし， $\gamma_{k}(t)$ : 逆起電力の過渡項である。コント ローラ内では積分器の作用により,

$$
i_{z 0}=i_{s k}+i_{\text {offk }}
$$

が定常状態で満足されていることから，

$$
e_{s k}+e_{\text {offk }}=R_{k}\left(i_{z 0}-i_{\text {off } k}\right)
$$

が成立する。ただし，添え字 $s$ : 定常状態を示す記号。

ここで， $i_{z 0}$ をゼロに設定してゼロパワー制御を行なった 場合の各コイルへの制御入力を $e_{s 0 k}$ とすれば, (19) 式より,

$$
e_{s 0 k}=-R_{k} i_{o f k}-e_{\text {offk }} \text {. }
$$

となる。(20) 式より，

$$
e_{o f f k}=-R_{k} i_{o f k}-e_{s 0 k}
$$

であるから (17) 式は,

$$
e_{k}-e_{s 0 k}=R_{k}\left(i_{k}+i_{\text {off } k}\right)+\gamma(t)
$$

と書き直すことができる。

(22) 式から，オフセット $e_{\text {offk }}, i_{\text {offk }}$ の混入がある場合に は， $R_{k}$ は次式で与えることができる。

$$
R_{k}=\frac{\left(i_{k}+i_{\text {off }}\right)\left(\frac{a_{32}}{b_{31}} \hat{\dot{z}}_{k}+\left(e_{k}-e_{s 0 k}\right)-\frac{1}{b_{31}} \frac{\mathrm{d} i_{k}}{\mathrm{~d} t}\right)}{\left(i_{k}+i_{o f f k}\right)^{2}+\varepsilon}
$$

ここで, $i_{k}+i_{o f f k}$ はコントローラ内に取り达まれるコイル 電流検出值となる。つまり, 抵抗推定の前に $i_{z 0}$ を一旦ゼロ に設定して $e_{s 0 k}$ を記憶し，次に $i_{z 0}$ を設定値に戻して記憶 した $e_{s 0 k}$ から (23) 式を演算すれば高精度の抵抗測定が行な える。

$$
\begin{aligned}
& \text { さらに, }(22) \text { 式から } i_{z 0} \text { がゼロのとき, } \\
& \begin{aligned}
e_{s 0 k} & =e_{k}-R_{k}\left(i_{k}+i_{o f f k}\right)-\gamma(t) \\
& \left.=e_{k}-R_{k}\left(i_{k}+i_{o f f k}\right)+\frac{a_{32}}{b_{31}} \hat{\vec{z}}_{k}-\frac{1}{b_{31}} \frac{\mathrm{d} i_{k}}{\mathrm{~d} t}\right\} \cdots \cdots
\end{aligned}
\end{aligned}
$$

が成立し， $e_{s 0 k}$ がリアルタイムで測定できる。 $\langle\mathbf{4} \cdot \mathbf{2}\rangle$ 推定值オフセット補償 各モードの制御系閉 ループにオフセット $e_{\text {off }}$ および $y_{\text {off }}$ が混入すると (9) 式よ り， $e_{\text {off }}$ および $y_{\text {off }}$ から速度推定值 $\hat{z}_{o b 2}$ までのそれぞれの伝 達関数直流分 $G_{e z}(0), G_{y z}(0)$ は,

$$
G_{e z}(0)=\frac{b_{31}}{a_{33}+a_{32} \alpha_{1}-\alpha_{3}}, \quad G_{y z}(0)=0 \ldots \ldots
$$

と計算される。したがって, D/A 变換器や電磁石駆動装置 の $e_{\text {off }}$ で速度推定值に定常偏差が生じることになる。速度 推定值に生じるオフセットは抵抗推定に誤差を生む。

ここでは, 速度推定值に定常偏差が発生しないようオブ ザーバの電圧入力 $e$ が補償できるよう, (6) 式の同一次元オ ブザーバを次のように修正する。

$$
\left.\begin{array}{l}
\dot{\boldsymbol{z}}_{\lambda}=\hat{\boldsymbol{A}}_{\lambda} \hat{z}_{\lambda}+\hat{\boldsymbol{B}}_{\lambda} y+\hat{\boldsymbol{E}}_{\lambda} e \\
\hat{\boldsymbol{x}}=\hat{\boldsymbol{C}}_{\boldsymbol{d}} \hat{z}_{\lambda}+\hat{\boldsymbol{D}}_{y}
\end{array}\right\} .
$$

ただし， $\hat{z}_{\lambda}$ :オブザーバ内部変数，オブザーバの

各行列 $\hat{A}_{\lambda}, \hat{\boldsymbol{B}}_{\lambda}, \hat{\boldsymbol{E}}_{\lambda}, \hat{\boldsymbol{C}}_{\lambda}$ はそれぞれ，

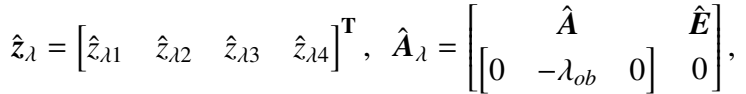

$$
\begin{aligned}
& \hat{\boldsymbol{B}}_{\lambda}=\left[\begin{array}{c}
\hat{\boldsymbol{B}} \\
0
\end{array}\right], \quad \hat{\boldsymbol{E}}_{\lambda}=\left[\begin{array}{l}
\boldsymbol{b} \\
0
\end{array}\right], \quad \hat{\boldsymbol{C}}_{\boldsymbol{d}}=\left[\begin{array}{ll}
\hat{\boldsymbol{C}}_{\boldsymbol{o b}} & \mathbf{0}_{3 \times 1}
\end{array}\right] .
\end{aligned}
$$

(6) 式のオブザーバと (26) 式の相違個所を図 5 に太線で 示す。

修正オブザーバを適用すると，(9) 式の拡大系は,

$$
\begin{aligned}
\mathrm{d} & {\left[\begin{array}{c}
\boldsymbol{x} \\
\mathrm{d} t \\
\hat{z}_{\lambda} \\
v
\end{array}\right]=} \\
& {\left[\begin{array}{ccc}
\boldsymbol{A}-\boldsymbol{b} \boldsymbol{F} \hat{\boldsymbol{D}} \boldsymbol{C} & -\boldsymbol{b} \boldsymbol{F} \hat{\boldsymbol{C}} \boldsymbol{D}_{\lambda} & -\boldsymbol{b} \boldsymbol{K} \\
\hat{\boldsymbol{B}}_{\lambda} \boldsymbol{C}-\hat{\boldsymbol{E}}_{\lambda} \boldsymbol{F} \hat{\boldsymbol{D}} \boldsymbol{C} & \hat{\boldsymbol{A}}_{\lambda}-\hat{\boldsymbol{E}}_{\lambda} \boldsymbol{F} \hat{\boldsymbol{C}} \boldsymbol{D}_{\lambda} & -\hat{\boldsymbol{E}}_{\lambda} \boldsymbol{K} \\
\boldsymbol{C} & \mathbf{0}_{1 \times 4} & 0
\end{array}\right]\left[\begin{array}{c}
\boldsymbol{x} \\
\hat{z}_{\lambda} \\
v
\end{array}\right] } \\
& +\left[\begin{array}{c}
\boldsymbol{d} \\
\mathbf{0}_{4 \times 1} \\
0
\end{array}\right] u-\left[\begin{array}{c}
\mathbf{0}_{3 \times 1} \\
\mathbf{0}_{4 \times 1} \\
1
\end{array}\right] y_{0}+\left[\begin{array}{c}
\boldsymbol{b} \\
\mathbf{0}_{4 \times 1} \\
0
\end{array}\right] e_{o f f}+\left[\begin{array}{c}
-\boldsymbol{b} \boldsymbol{F} \hat{\boldsymbol{D}} \\
-\hat{\boldsymbol{E}}_{\lambda} \boldsymbol{K} \hat{\boldsymbol{D}} \\
1
\end{array}\right] y_{o f f}
\end{aligned}
$$

と書き直せる。ただし，

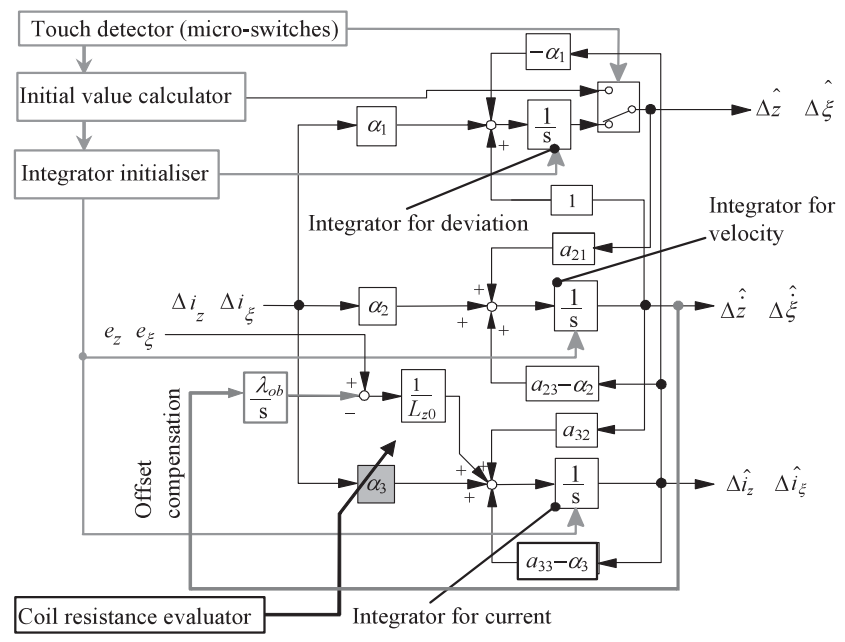

図 5 修正同一次元オブザーバ

Fig. 5. Modified full order state observer. 


$$
\boldsymbol{D}_{\lambda}=\left[\begin{array}{ll}
\boldsymbol{D}_{o b} & \mathbf{0}_{2 \times 1}
\end{array}\right], \quad \hat{\boldsymbol{D}}_{\lambda}=\left[\begin{array}{ll}
\boldsymbol{C} & 0
\end{array}\right]^{\mathbf{T}}, \quad \hat{\boldsymbol{C}}_{\lambda}=\boldsymbol{D}_{\lambda}{ }^{\mathrm{T}} .
$$

(27) 式より， $e_{\text {off }}$ および $y_{\text {off }}$ から速度推定值 $\hat{z}_{\lambda 2}$ までのそ れぞれの伝達関数直流分 $G_{\lambda e z}(0), G_{\lambda y z}(0)$ を計算すると, こ れらはともにゼロとなる。したがって，制御系閉ループに オフセットが混入しても速度推定值 $\hat{z}_{o b 2}$ に定常偏差は生じ なくなる。

〈4·3〉 フィードバックゲインの適応化フィードバッ クゲイン $\boldsymbol{F}, \boldsymbol{K}$ のうち, コイル抵抗值 $R$ で変動するのは (13) 式から $a_{33}$ を含む $F_{3}$ だけである。(5) 式のモード別状態方 程式中のコイル抵抗值 $R$ は (15) 式の補正電圧 $e_{c}$ で平均の コイル抵抗值 $R_{a}$ に置換されるので，(23) 式で得られる各 コイルのコイル抵抗推定值 $R_{k}$ を用いて $F_{3}$ は,

$$
F_{3}=-\frac{1}{n} \sum_{k=1}^{n} R_{k}+\frac{c_{3}}{b_{31}}=-R_{a}+\frac{c_{3}}{b_{31}}
$$

で与えられる。同様に，オブザーバについても $R_{k}$ を用いて (14) 式を書き換え,

$$
\alpha_{3}=-\frac{R_{a}}{L_{z 0}}+\frac{6}{\sigma}
$$

で適応オブザーバを構成する。

\section{5. センサレス浮上特性}

吸引形磁気浮上では, 構造物の機械共振回避や, 軌道不 整に対する振動絶縁のため比較的低ゲインのフィードバッ ク制御を適用することが多い。低ゲインでは，

(1) (12) 式で $s$ の係数 $c_{i}(i=1 \sim 4)$ が小さくなる。

(2) 係数 $c_{i}(i=1 \sim 4)$ について, たとえば特性方程式が $(s+\lambda)^{4}=0(\lambda \gg 2)$ の場合では $\mathrm{c} 3<\mathrm{c} 2<\mathrm{c} 1<\mathrm{c} 0$ となる。

(3) $a_{21}, a_{23}, b_{31}$ の HM 磁気特性に依存する項が (13) 式および (7) 式の分母分子にあると磁気特性の変動 が相殺される傾向にある。

(4) $a_{32}$ は HM 磁気特性で分母分子が相殺される傾向に ある。

等を考慮すると質量，慣性モーメント，コイル抵抗および HM 自己インダクタンスの変動が浮上制御系のロバスト安 定性に影響しやすくなる。本章では, 実験装置の $\mathrm{z}$ モード を例に，センサレス磁気浮上制御の浮上特性を明らかにす る。装置の諸元を表 1 に示す。また，特性計算にもちいた フィードバック定数を表 2 に示す。

〈5・1〉 コイル抵抗值の変動センサレス磁気浮上系 でコイル抵抗変動に対する適応制御を行わなかった場合の 根軌跡を図 6 に示す。計算には (27) 式右辺第一項のシステ ム行列を用いた。ノミナル值の $\pm 1 \%$ のコイル抵抗值変動で 系が不安定になることがわかる ${ }^{(16)}$ 。

コイル抵抗值変動に対する適用制御を用いた場合，浮上 制御系のロバスト安定性は後述の実験で示すように飛躍的 に向上する。

\begin{tabular}{|c|c|c|c|c|}
\hline \multicolumn{5}{|c|}{ Door Body } \\
\hline Mass: $M$ & $12.2\left(14.0^{*}\right)(\mathrm{kg})$ & Inertia: $I_{\xi}$ & $1.71\left(2.49^{*}\right)$ & $\left(\mathrm{kgm}^{2}\right)$ \\
\hline HM units span: $l_{\xi}$ & 0.38 & Demensions & $500^{\mathrm{W}} \times 1014^{\mathrm{h}} \times 40^{\mathrm{t}}$ & $(\mathrm{mm})$ \\
\hline Gap width: $z_{r}$ & $4.1\left(3.7^{*}\right)(\mathrm{mm})$ & Ceiling height & 1020 & $(\mathrm{~mm})$ \\
\hline \multicolumn{5}{|c|}{ Magnet unit } \\
\hline length: $L_{m}$ & $60 \quad(\mathrm{~mm})$ & $\partial F_{z} / \partial z$ at $z_{r}$ & $19390(23760 *)$ & $(\mathrm{N} / \mathrm{m})$ \\
\hline Width: $W_{m}$ & $35 \quad(\mathrm{~mm})$ & $\partial F_{z} / \partial i$ at $z_{r}$ & $-21.42\left(-24.52^{*}\right)$ & (N/A) \\
\hline Height: $h_{m}$ & $(\mathrm{~mm})$ & $\partial \Phi_{z} / \partial z$ at $z_{r}$ & $-32.58(-37.31 *)$ & $(\mathrm{mWb} / \mathrm{m})$ \\
\hline \multicolumn{2}{|c|}{ Electromagnet } & $L_{z 0}$ at $z_{r}$ & $54.78\left(56.31^{*}\right)$ & $(\mathrm{mH})$ \\
\hline Resistance: $R$ & $7.63 * \quad(\Omega)$ & \multicolumn{3}{|c|}{ Ceiling } \\
\hline \multirow[t]{2}{*}{ Number of turns: $N$} & (Turn) & Aluminum panel & $1.0^{\mathrm{t}}$ & $(\mathrm{mm})$ \\
\hline & & \multicolumn{3}{|c|}{ Iron plate } \\
\hline $\mathrm{Nd} \cdot \mathrm{Fe} \cdot \mathrm{B}$ & $30^{\mathrm{l}} \times 35^{\mathrm{W}} \times 19^{\mathrm{h}}(\mathrm{mm})$ & Thickness & 6 & $(\mathrm{~mm})$ \\
\hline
\end{tabular}

表 1 諸元

Table 1. Mechanical and Electrical Parameters.

\begin{tabular}{|c|c|c|c|c|c|c|c|}
\hline \multicolumn{5}{|c|}{ Observer } & \multirow{2}{*}{\multicolumn{3}{|c|}{$\begin{array}{c}\text { Feedback controller } \\
z \text { mode } \\
\end{array}$}} \\
\hline & \multicolumn{2}{|c|}{$z$ mode } & \multicolumn{2}{|c|}{$\xi$ mode } & & & \\
\hline$a_{21}$ & 3346.5 & $\left(1 / \mathrm{s}^{2}\right)$ & 1002.3 & $\left(1 / \mathrm{s}^{2}\right)$ & $F_{1 z}$ & -2803.8 & $(\mathrm{~V} / \mathrm{m})$ \\
\hline$a_{23}$ & -3.3365 & $\left(\mathrm{~m} / \mathrm{s}^{2} / \mathrm{A}\right)$ & -1.034 & $\left(\mathrm{rad} \mathrm{m} / \mathrm{s}^{2} / \mathrm{A}\right)$ & $F_{2 z}$ & -54.792 & $(\mathrm{~V} \mathrm{~s} / \mathrm{m})$ \\
\hline$a_{32}$ & 634.01 & $(\mathrm{~A} / \mathrm{m})$ & 600.39 & $(\mathrm{~A} / \mathrm{rad} / \mathrm{m})$ & $F_{3 z}{ }^{*}$ & -5.1602 & $(\mathrm{~V} / \mathrm{A})$ \\
\hline$a_{33} *$ & -139.57 & $(1 / \mathrm{s})$ & -141.61 & $(1 / \mathrm{s})$ & $K_{3 z}$ & -0.69234 & $(\mathrm{~V} / \mathrm{As})$ \\
\hline$\alpha_{1}$ & 1.1790 & $(\mathrm{~m} / \mathrm{s} / \mathrm{A})$ & 1.7769 & $(\mathrm{~m} / \mathrm{s} / \mathrm{A})$ & \multicolumn{3}{|c|}{$\xi$ mode } \\
\hline$\alpha_{2}$ & 56.080 & $\left(\mathrm{~m} / \mathrm{s}^{2} / \mathrm{A}\right)$ & 29.466 & $\left(\mathrm{rad} \mathrm{m} / \mathrm{s}^{2} / \mathrm{A}\right)$ & $F_{1 \xi}$ & -1326.9 & $(\mathrm{~V} / \mathrm{rad})$ \\
\hline$\alpha_{3}{ }^{*}$ & 130.06 & $(1 / \mathrm{s})$ & 60.010 & $(1 / \mathrm{s})$ & $F_{2 \xi}$ & -59.140 & $(\mathrm{~V} \mathrm{~s} / \mathrm{rad})$ \\
\hline \multicolumn{5}{|c|}{ HM self-inductance } & $F_{3 \xi^{*}}$ & -6.3647 & $(\mathrm{~V} / \mathrm{A})$ \\
\hline$L_{z 0}$ & 56.31 & $(\mathrm{mH})$ & 56.31 & $(\mathrm{mH})$ & $K_{3 \xi}$ & -0.27343 & $(\mathrm{~V} / \mathrm{A} \mathrm{s})$ \\
\hline
\end{tabular}

表 2 制御定数

Table 2. Control parameters.

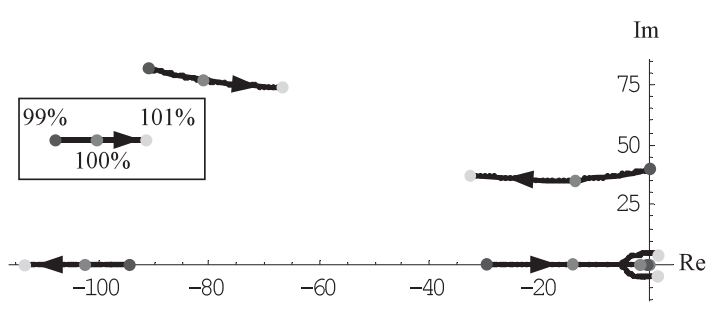

図 6 抵抗值変動に対する根軌跡

Fig. 6. Root loci for coil resistance variation.

〈5・2〉自己インダクタンスの変動 $\mathrm{HM}$ コイルの自己 インダクタンスがノミナル值に対して $-7.5 \%$ ～5\%変動し た場合の根軌跡を図 7 に示す。前節と同様, 計算には (27) 式を用いた。

コイル抵抗と異なり，給電線を含む $\mathrm{HM}$ の自己インダク タンスはシステムの仕様が決まればほとんど変動しない。 図 7 の根軌跡は $L_{z 0}$ が $\pm 1 \%$ 程度の誤差で求まれば, 浮上の ためのチューニングが不要となることを示している。

$\langle\mathbf{5} \cdot \mathbf{3}\rangle$ 質量の変動 質量の変動に対する根軌跡を 図 8(a)に示す。計算には(27) 式を用いた。同図での質量変 動はノミナル值の - 10\%から 50\%である。50\%の質量変動 に対しても代表根の移動は僅かであり, 質量変動に対してセ ンサレス磁気浮上系は強いロバスト安定性を示すことがわ 


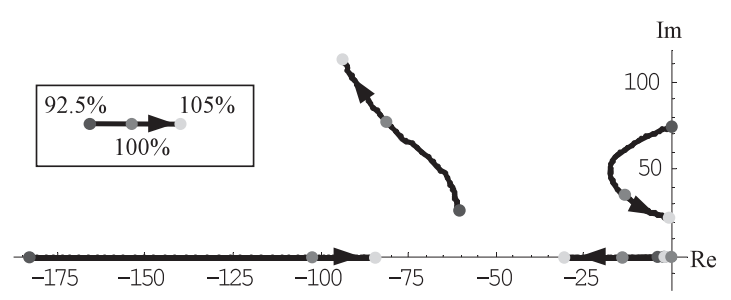

図 $7 \quad L_{z 0}$ の変動に対する根軌跡

Fig. 7. Root loci for self-inductance variation.

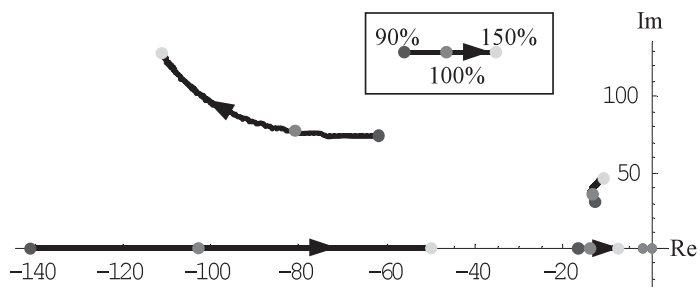

(a) Self-gap-detecting control.

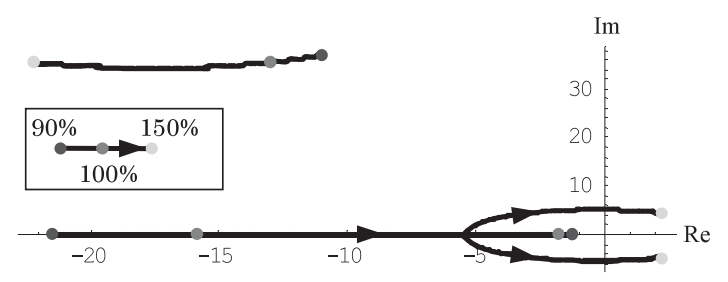

(b) Control with gap detectors.

図 8 質量変動に対する根軌跡

Fig. 8. Root loci for mass variation.

かる。一方，オブザーバの代わりにギャップセンサから浮 上ギャップ長とその速度を検出した場合の根軌跡を図 8(b) に示す。計算には (11) 式左辺二項を用いた。この図で軌跡 と虚軸の交点は質量増加が 37\%の時である。図 8(a)に比 べ，小さな質量増加で代表根が不安定領域に移動する。

質量変動に対する強いロバス卜安定性は，オブザーバ方 式センサレス磁気浮上の特長である。コイル抵抗の変動に ロバスト安定性が不足する反面，質量変動に対しては高い ロバスト安定性を有する。

なお，図 6から図 8(a) において，実軸上の原点近くに二 つのノミナル質量の代表根が存在するが，原点に近い方は -0.2 近傍に存在し，(26) 式の速度推定值オフセット補償に 起因する根である。もう一方は図 8(b) の原点に近い代表根 と同様，(11) 式左辺二項の特性根の一つである。これら二 つは，-10\%から 50\%の質量変動に対してほとんど移動し ない。

\section{6. 浮上実験}

実験では，閉ループ系のオフセット電圧推定を行なうた め次のシーケンスを導入した。

(1) 電流目標值 $i_{z 0}$ を 200 秒周期で 10 秒間ゼロに設定して ゼロパワー制御を行う。電流目標值 $i_{\xi 0}$ は常にゼロに設定。

(2) ゼロパワー制御の間，コイル抵抗值演算をホールド するとともに各コイルの電流が所定範囲内であればゼロパ

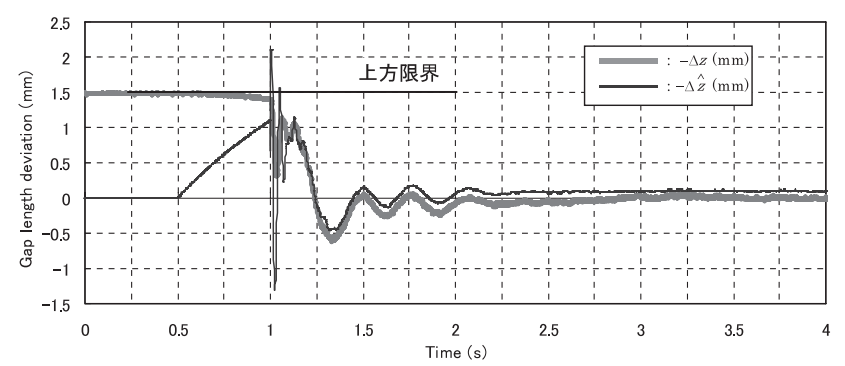

図 9 浮上開始応答 $\left(R_{1}: 7.44(\Omega), R_{2}: 7.37(\Omega)\right)$

Fig. 9. Start response $\left(R_{1}: 7.44(\Omega), R_{2}: 7.37(\Omega)\right)$.

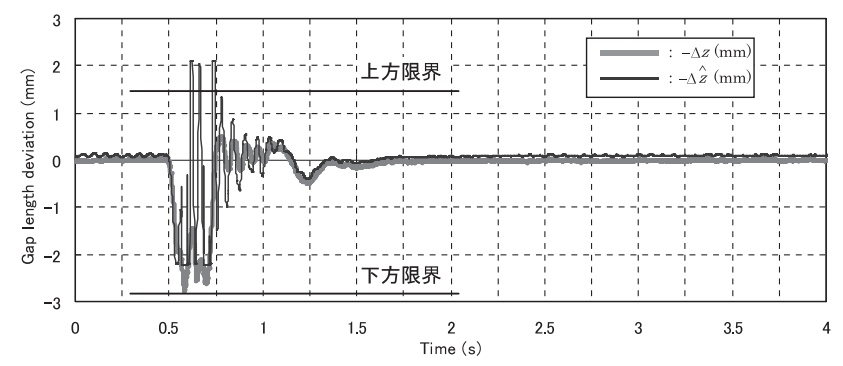

図 10 過大外乱応答 $\left(R_{1}: 7.48(\Omega), R_{2}\right.$ ： $7.34(\Omega))$

Fig. 10. Recover response $\left(R_{1}: 7.48(\Omega), R_{2}: 7.34(\Omega)\right)$.

ワー制御終了直前の制御入力 $e_{k}$ の -1 倍を閉ループ系オフ セット電圧 $-e_{s 0 k}\left(=R_{k} i_{o f f k}+e_{o f f k}\right)$ として取込み前回のデー 夕を更新する。

(3) 各コイルの電流が所定範囲を超えた場合はその時点で ゼロパワー制御を解除し， 200 秒の周期をリセットする。

(4) 残りの 190 秒は電流目標值 $i_{z 0}$ を $-100 \mathrm{~mA}$ に変更し, オフセット電圧測定データを基に (23) 式でリアルタイムに コイル抵抗值を演算するとともに, 演算結果をオブザーバ, 非干渉電圧補償器拉よびフィードバックゲイン補償器に取 り込んでそれぞれの適応パラメータをサンプリング周期で 変更する。

なお，(24) 式の $e_{s 0 k}$ は時定数 0.5 秒のローパスフィル夕 を介して検出し，(23) 式の $R_{k}$ の推定には時定数 1.0 秒の ローパスフィルタを使用した。コントローラは 16 ビット DSP でサンプリング周期は $110 \mu \mathrm{s}$ ，ドライバはパワーアン プである。

〈6.1 浮上開始・復帰実験 質量 $14.2 \mathrm{~kg}$ の浮上体が 天井に吸着した状態から浮上を開始するときの応答を図 9 に，過大外乱として浮上中の浮上体を下方に引下げ，底部 を床に衝突させたときの再浮上の応答を図 10 に示す。浮 上開始操作ではコイル抵抗值推定完了後に浮上体の姿勢で 決まるギャップ長がローパスフィルタを介してギャップ推 定值として時刻 0.5 秒で出力されている。ギャップ長推定 值の増加でゲイン $F_{1 z}$ を介して磁石ユニットが励磁される と, 吸引力が減少してマイクロスイッチのバネ効果で磁石 ユニットが天井（上方限界）から徐々に離れる。浮上体が 浮上してオブザーバが演算を開始すると $\Delta \hat{z}$ がパルス状の 過渡応答を示し， 0.2 秒後には推定值と目標值が一致する。 

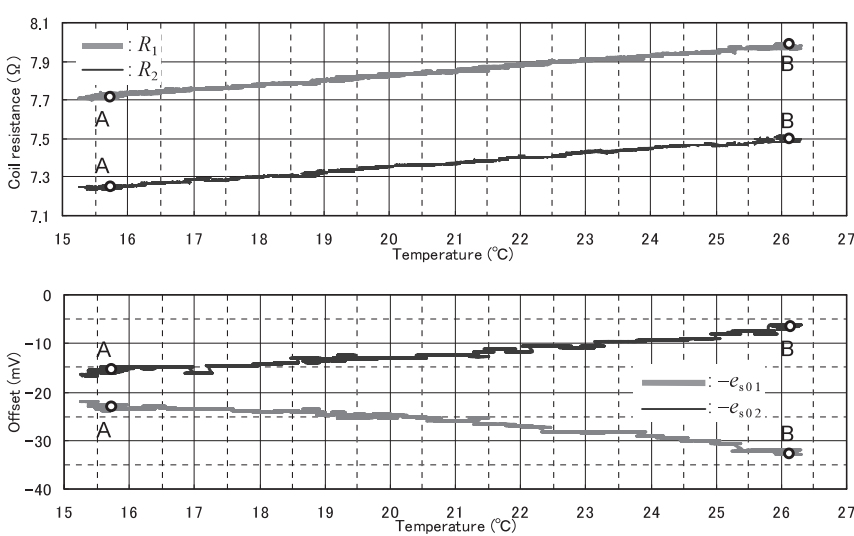

図 11 室温とコイル抵抗およびオフセット電圧 の関係

Fig. 11. Coil resistances and offset voltages for room temperature.

図 10 では時刻 0.5 秒で浮上体に過大外乱が加えられてい る。接触時にマイクロスイッチの動作でオブザーバが初期 化され，下方限界付近で $\Delta \hat{z}$ が予め決められた值 $2.2(\mathrm{~mm})$ を出力していることが確認できる。三回の初期化の後, 外 乱の印加から 0.5 秒程度で $\Delta \hat{z}$ は $\Delta z$ の応答に収束し, 安定

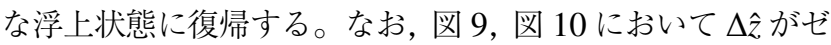
ロに収束しないのは, $i_{z 0}$ が $-100 \mathrm{~mA}$ に設定されているため である。また，マイクロスイッチのストロークは $0.5 \mathrm{~mm}$, 機械的寸法で決まる上方限界と下方限界の間隔は $4.3 \mathrm{~mm}$ である。以下の図では，ギャップ長推定值 $\Delta \hat{z}$ と測定值 $\Delta z$ 拉よび測定值 $\Delta z$ と $l_{\xi} \Delta \xi$ の比較のため, 定常浮上状態での ギャップセンサ出力值をギャップ長定常偏差の原点とする。

〈6・2 抵抗值・オフセット測定試験＼cjkstart室温を変化させ た場合の $R_{1}, R_{2}$ 抢よび $e_{s 01}, e_{s 02}$ の推定結果を図 11 に示 す。また，図 11 中の点 $\mathrm{A}, \mathrm{B}$ に打いて, 質量 $14.2 \mathrm{~kg}$ の浮 上体重心付近に時刻 1.0 秒で $z$ 方向の打撃を加えた場合の $z, \xi$ モードに扮ける測定值 $\Delta z, l_{\xi} \Delta \xi$ のインパルス応答を 図 12 に示す。図 13 に $R_{1}: 7.48(\Omega), R_{2}: 7.41(\Omega)$ で (15) 式の補正電圧 $\boldsymbol{e}_{c}$ による制御軸の非干渉化を行なわなかった 場合のインパルス応答を示す。打撃時刻は 0.75 秒である。

図 13 での抵抗值の差は $0.07(\Omega)$, ノミナル值の $1 \%$ であ るが, $\xi$ モードに $z$ モードと同程度の振幅で動摇が生じ，そ の動摇が干渉により両モード間を循環している。図 12 で

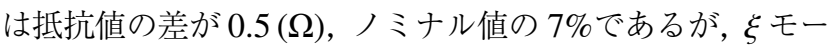
ドの振幅は $1 / 3$ 以下になっている。このことから, 図 11 に おける $R_{1}, R_{2}$ および $e_{s 01}, e_{s 02}$ のリアルタイム推定の妥当 性が検証できる。また，1\%のコイル抵抗值変動で不安定に なる図 6 のセンサレス磁気浮上制御系において, $R_{1}, R_{2}$ が 個々に $2 \%(0.15(\Omega))$ 以上変動しても過渡応答がほぼ一致 していることから適応制御の効果が確認できる。

$\langle\mathbf{6} \cdot \mathbf{3}\rangle$ 限界試験 付加抵抗をすべて外したコイル抵 抗值下方限界，片側コイルの給電飽和限界および浮上開始 可能限界におけるインパルス応答を図 14 に示す。片側コ イルの給電飽和限界は使用した電源電圧で浮上開始のため

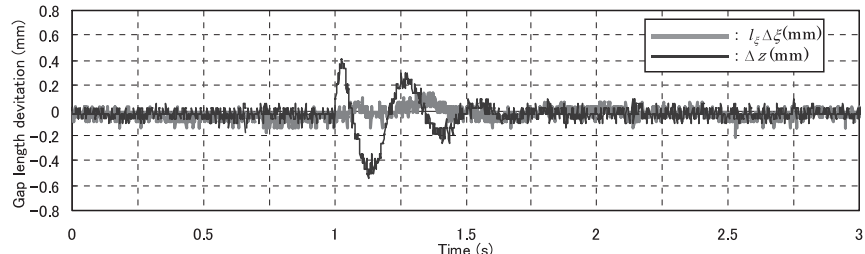

(a) Point A: Temperature $15.7\left({ }^{\circ} \mathrm{C}\right)\left(R_{1}: 7.72(\Omega), R_{2}: 7.25(\Omega)\right)$

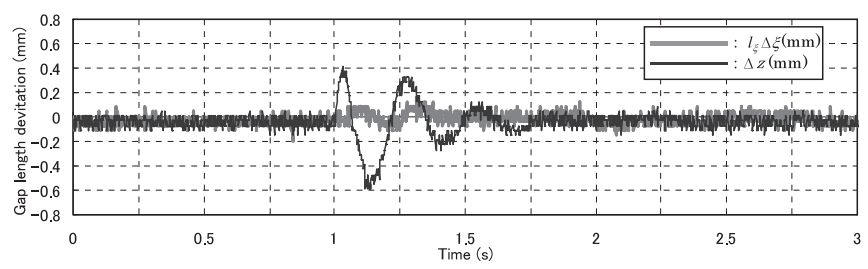

(b) Point B: Temperature $26.1\left({ }^{\circ} \mathrm{C}\right)\left(R_{1}: 7.98(\Omega), R_{2}: 7.50(\Omega)\right)$

図 12 点 $\mathrm{A}$, 点 $\mathrm{B}$ におけるインパルス応答

Fig. 12. Impulse responses at Point A \& B.

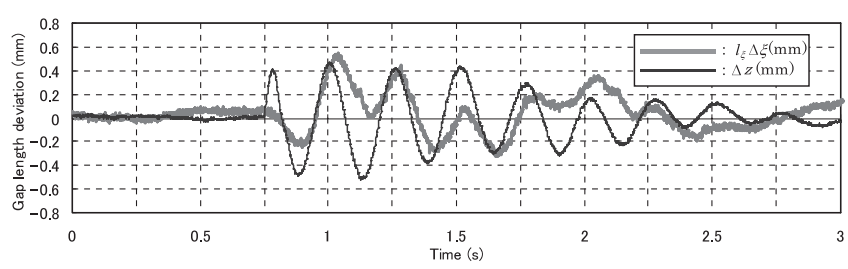

図 13 非干渉化電圧補正を施さない場合のイン パルス応答

Fig. 13. Impulse response out of anti-interaction compensation.

の電流が飽和するコイル抵抗值であり，浮上開始可能限界 は浮上開始時の過渡応答の収束が悪いためスムーズな浮上 開始が出来なくなるコイル抵抗值である。それぞれの場合 で打撃時刻は 0.75 秒である。図 14 から, 平均の抵抗值 $R_{a}$ が大きくなるほど系の振動減衰が弱くなっている。これは, コイル自己インダクタンスの同定誤差でノミナルモデルの 時定数が抵抗值に依存して変動するためと考えられる。

図 14 はコイル抵抗值適応制御に限界があることを示して いるが, この場合のコイル抵抗変動幅はノミナル值の $60 \%$ あり，実用上十分なマージンである。

浮上体の質量をノミナル值の $50 \%$ 範囲, $-2 \mathrm{~kg}$ から $5 \mathrm{~kg}$ まで変動させた場合のトリガ時刻 0.75 秒でのインパルス 応答を図 15 に示す。質量 $14.2(\mathrm{~kg})$ の図 12 の場合に比べ, 質量が増大寸るほど振動的でなくなることがわかる。質量 $12.2(\mathrm{~kg})$ では浮上ギャップ長調整用の錘がすべて外されて いる。また，質量 $19.2(\mathrm{~kg})$ ではステップ応答が採取できる 最小機械的ギャップ長 $1 \mathrm{~mm}(z=2.82(\mathrm{~mm})$ が確保されて いる。図 15 は，ノミナル值の $50 \%$ に相当する質量変動に もかかわらず，浮上ギャップ長の測定值と推定值はほぼ一 致することを示している。

図 8(a) の根軌跡では質量が重くなると実軸上の極が代表 根となり, 軽くなると虚数部を持つ極が代表根となる。こ の根軌跡と本実験結果の傾向は一致しており，オブザーバ 方式のセンサレス磁気浮上制御が質量変動に対して高いロ 


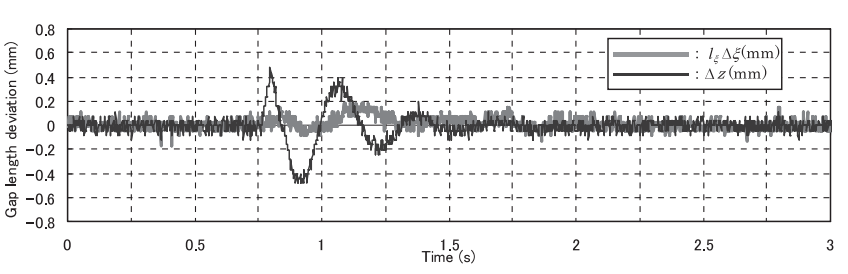

(a) $R_{1}: 6.87(\Omega), R_{2}: 6.77(\Omega)\left(R_{a}=6.82(\Omega)\right)$

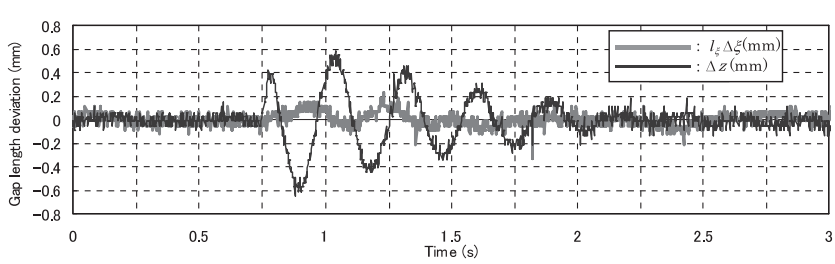

(b) $R_{1}: 13.61(\Omega), R_{2}: 7.35(\Omega)\left(R_{a}=10.48(\Omega)\right)$

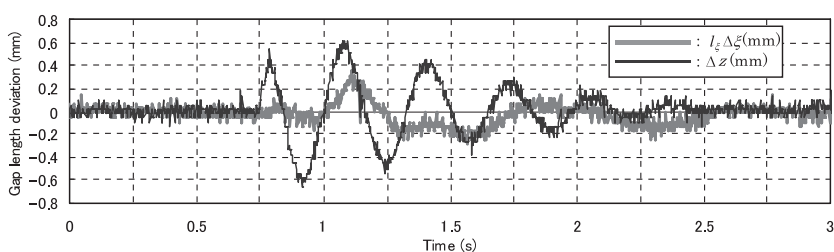

(c) $R_{1}: 11.38(\Omega), R_{2}: 11.37(\Omega)\left(R_{a}=11.38(\Omega)\right)$

図 14 コイル抵抗值限界におけるステップ応答

Fig. 14. Impulse responses on the border of allowable coil resistance range.

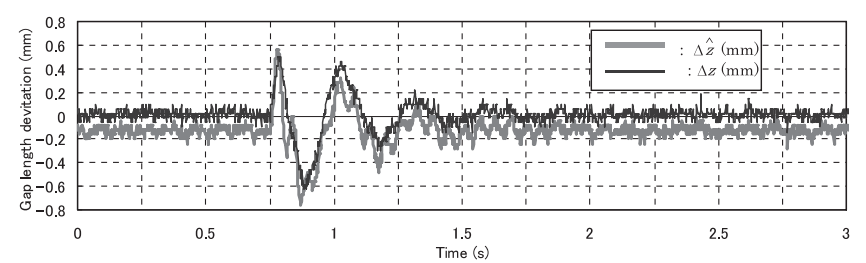

(a) $M: 12.2(\mathrm{~kg})\left(R_{1}: 7.34(\Omega), R_{2}: 7.30(\Omega)\right)$

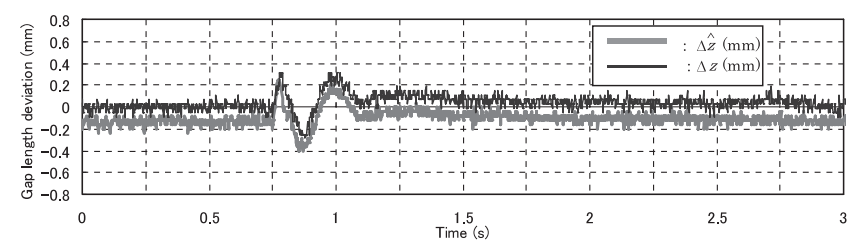

(b) $M: 19.2(\mathrm{~kg})\left(R_{1}: 7.34(\Omega), R_{2}: 7.33(\Omega)\right)$

図 15 質量限界におけるステップ応答

Fig. 15. Impulse responses on the border of allowable mass range.

バスト安定性を有することが確認できる。

\section{7. むすび}

オブザーバ方式のセンサレス磁気浮上制御にコイル抵抗 值適応制御を導入すると，コイル抵抗值変動に対して実用 上十分なロバスト安定性が得られた。また，ギャップセン サを用いた磁気浮上制御に比べ，本センサレス制御が質量 や慣性モーメントの変動に対してより高いロバスト安定性 を示すことが明らかとなった。

本研究では，ゼロパワー制御による閉ループ系のオフセッ
卜電圧測定により，0.1\%程度の精度でコイル抵抗值を検出 している。この手法に限らず，オフセット電圧やコイル温 度を一定に保てば高精度なコイル抵抗值推定が可能である。 特に, ゼロパワー制御を適用しない場合はバイアス励磁電 圧が大きくなり，閉ループ系オフセット電圧を無視しても 抵抗推定誤差が小さくなる。このため, 通常の吸引式磁気 浮上ではオフセット電圧の推定が不要となる。

オブザーバ方式センサレス磁気浮上は,

(1) 接触時のオブザーバ積分器のリセット

(2) コイル抵抗值適応制御

(3) 不均一コイル抵抗による制御軸間干渉電圧補正 の三つの機能追加で実用に十分なロバスト安定性が実現で きる。今後, 本制御方式のエレベータ非接触案内装置への 適用を進めていく。

センサレス磁気浮上制御に関する本研究が産業応用にお ける磁気浮上制御技術の新展開に資すれば幸いである。

謝 辞

最後に，本研究を進めるにあたり多大なご支援をいただ いた当社電力. 社会システム技術開発センター田井一郎前 センター長, 同センター 須藤亮現センター長に深く感謝い たします。

(平成 17 年 12 月 20 日受付，平成 18 年 6 月 21 日再受付)

\section{文献}

（1）電気学会磁気浮上応用技術調查専門委員会編：「磁気浮上と磁気軸 受」, コロナ社 (1993)

(2) B.V. Jayawant: "Electromagnetic Levitation and Suspension Techniques", Edward Arnold, London (1981)

(3) P.K. Sinha: "Electromagnetic Suspension Dynamics \& Control", Peter Peregrinus, Ltd., London (1987)

(4) M. Morishita and T. Azukizawa: "Zero Power Control Method for Electromagnetic Levitation System", Trans. IEE of Japan, Vol.108-D, No.5, p.447 (1988-5) (in Japanese)

森下明平・小豆沢照男 :「常電導吸引式磁気浮上系のゼロパワー制 御」, 電学論 D, 108, 5, p.447 (1988-5)

(5) M. Morishita and M. Akashi: "Electromagnetic Non-contact Guide System for Elevator Cars", LDIA'01 Int. Symposium, pp.416-419, Nagano (200110)

(6) M. Morishita and H. Itoh: "The Self-Gap-Detecting Electro-magnetic Suspension System for Doors", LDIA'03 Int. Symposium, pp.141-144, Birmingham (2003-9)

（7）水野 毅, 他：「変位センサレス磁気軸受の実用化に関する研究」, 電 学論 D, 116, 1, p.35 (1996-1)

(8) S. Moriyama: "AC Magnetic Suspension Using Differential Feedback Power Amplifier", No.1215, 1997 National Convention Record I.E.E. Japan, 5 (1997)

森山伸一：「差動帰還形パワーアンプを用いた AC 磁気浮上」, No. 1215 , 平 9 電全大, 5 (1997)

（9）水野 毅, 他：「ヒステリシスアンプを利用したセルフセンシング 磁気浮上」,計測自動制御学会論文集, Vol.32, No.7, p.1043 (1996)

（10）例えば, 岩井善太・井上 昭・川路茂保：「オブザーバ」,コロナ社 (1988)

(11) M. Morishita and M. Akashi: "Guide-effective Levitaion Control for Electromagnetic Suspension System”, Trans. IEE of Japan, Vol.119-D, No.10, p. 1259 (1999)

森下明平 ·明石征邦 :「常電導吸引式磁気浮上系の浮上案内干渉制 御」, 電学論 D, 119, 10, p.1259 (1999)

(12) M. Morishita, et al.: "Zero Power Control for Maglev System of A Rigid Body Vehicle with Multi-suspended Points", Trans. IEE of Japan, Vol.120D, No.4, p.509 (2000)

森下明平, 他：「多点支持式剛体磁気浮上車両のゼロパワー制御」, 電 
学論 D, 120, 4, p.509 (2000)

(13) M. Morishita: "The Coil Electric Resistance Variation and Stability of Selfgap-detecting Maglev Systems", The papers of Technical Meeting on Linear Drives IEEJ, LD-04-50 (2004) 59

森下明平：「コイル抵抗值変動がセンサレス磁気浮上系の安定性に 及ぼす影響とその対策」,リニアドライブ研資, LD-04-50 (2004) 59

(14) M. Morishita: "A Relationship between Equality of Coil Resistances and Stability of Electromagnetic Suspensions", No.5-079, 2005 National Convention Record I.E.E. Japan (2005)

森下明平:「常電導吸引式磁気浮上系におけるコイル抵抗值の均一 性と浮上安定性の検討」, No. 5-079, 平 17 電全大, 5 (2005)

(15) M. Morishita and M. Akashi: "A Study of Elevator Car Non-Contact Guide System with An Electromagnetic Suspension under Zero Power Control", The papers of Technical Meeting on Linear Drives IEEJ, LD-01-53 (2001) 17

森下明平・明石征邦：「ゼロパワー磁気浮上制御によるエレベータ 非接触案内方式の検討」, リニアドライブ研資, LD-01-53 (2001) 17

(16) M. Morishita and H. Itoh: "Gap-sensor-less Maglev System Sta-bility for Electric Resistance of Coil", No.5-073, 2004 National Convention Record I.E.E. Japan (2004)

森下明平・伊東弘晃：「ギャップセンサレス磁気浮上制御系のコイ 儿抵抗值変動と安定性」, No.5-073, 平 16 電全大, 5 (2004)
森 下 明 平 (正員) 1957 年 1 月 25 日生。1982 年 3 月早稲

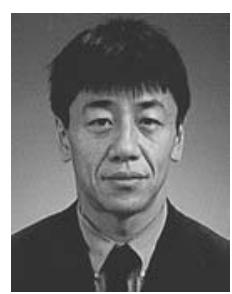
田大学大学院修士課程（電気工学専攻）修了。同 年 (株) 東芝に入社。主として常電導吸引式およ び超電導誘導反発式磁気浮上, 高温超電導体のピ ン止め効果による磁気浮上の研究開発に従事。現 在, 同社電力・社会システム技術開発センター主 査。日本機械学会会員。博士 (工学)。

伊東 弘 晃（正員） 1974 年 9 月 27 日生。1999 年 3 月早稲

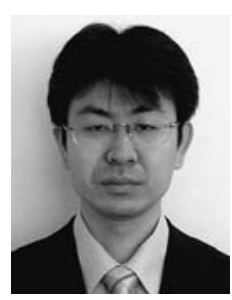
田大学大学院修士課程（機械工学専攻）修了。同 年 (株) 東芝に入社。主として常電導吸引式磁気 浮上，および昇降機技術の研究開発に従事。現在， 同社電力・社会システム技術開発センターに所属。 日本機械学会会員。 